\title{
TERAPI REMINISCENCE TERHADAP PENURUNAN TINGKAT KECEMASAN PASIEN HEMODIALISA DI RUANG HEMODIALISA RSUD NGANJUK
}

\author{
Heru Wahyudi ${ }^{1}$, Irinjayani Kartika Putri ${ }^{2}$, Ganda Ardiansyah ${ }^{3}$ \\ ${ }^{123}$ STIKes Satria Bhakti Nganjuk \\ Email : heroowow77@gmail.com
}

\begin{abstract}
Background.Chronic renal failure patients who undergone hemodialysis treatment tend to experience anxiety. Reminiscence therapy by utilize patient's very own past memorable and fun event can reduce the anxiety levels. This study aims to determine the effect of reminiscence therapy to decrease the level of anxiety. Method. This research utilized pre Experimental One Group Pre-Post Test Design method, conducted on 18 February throughout 20 March 2018.There were 16 respondents of population, 15 respondents were applied as sample by purposive sampling technique. Reminiscence therapy was utilized as independent variable, anxiety levels was used as dependent variable. Wilcoxon sign rank test with $\alpha=0,05$, was applied in statistical data analysis, Hospital Anxiety and Depression Scale (HADS) was applied as instrument in assessment. Results. From 16 respondents mostly as much as 8 respondents $(53,3 \%)$ before the reminiscence therapy was administered showed that had moderate anxiety levels, after reminiscence therapy was administered there was decliene in anxiety levels who resolved to mild anxiety levels which is 14 respondents $(93 \%)$. The statistical test by utilize wilcoxon sign rank test showed $\rho$ value $=0,007, \rho$ value $\leq \alpha=0,05$, so Ha was accepted, it means there was influence of reminiscence therapy to decrease the anxiety levels of hemodialysis patients at Hemodialysis Wards of RSUD Nganjuk. Conclusion. Reminiscence therapy showed efficacy inlowered anxiety. Reminiscence therapy motivated respondents by influence positive coping through willingness and openness to remember and retell the memorable and fun of the past events. So the anxiety experienced by hemodialysis patients would be decreased. Reminiscence therapy could be performed by a nurse, it corresponds with the framework of nursing which is roles of nurses as a counselor.
\end{abstract}

Keywords : Reminiscence Therapy, Anxiety Rate, Hemodialysis Sufferers

\section{PENDAHULUAN}

Gagal ginjal kronik saat ini telah menjadi suatu masalah kesehatan publik di seluruh dunia. Hal ini diakui sebagai suatu kondisi umum yang dikaitkan dengan peningkatan penyakit jantung dan gagal ginjal kronik (Jevuska, 2012). Pasien penyakit ginjal stadium akhir (ESRD) yang menjalani hemodialisis juga ditemukan dengan banyak tekanan fisik dan psikososial yang berdampak negatif terhadap kualitas hidup pasien
(Masoudrayyani, M., L., Forouzi, M.A., dan Razban, F., 2014). Irmawati (2008) dalam Slametiningsih (2012) pasien gagal ginjal kronik yang menjalani terapi hemodialisa baik pasien baru maupun pasien yang sudah lama menjalani hemodialisa cenderung mengalami kecemasan. Studi pendahuluan dari hasil wawancara pada tanggal 17 Oktober 2017 terhadap 7 orang pasien hemodialisa di Ruang Hemodialisa RSUD Nganjuk, dua 
orang mengatakan terkadang merasa sulit tidur apabila memikirkan bagaimana masa depannya, merasa ada rasa takut akan sesuatu yang tidak diinginkan tiba-tiba terjadi. Tiga orang mengatakan terkadang terpikirkan dan terbayangkan hal-hal yang buruk terhadap kondisinya saat ini, dan jika teringat kondisinya dan bagaimana masa depannya menjadi tidak nafsu makan. Dua orang mengatakan jika memikirkan kondisinya saat ini tiba-tiba merasa lemas, muncul keringat dingin dan gelisah sehingga merasa semua di hidup ini sudah berakhir. Dan hasil observasi peneliti, belum ada penatalaksanaan keperawatan yang spesifik untuk mengatasi kecemasan pada pasien hemodialisa di ruang Hemodialisa RSUD Nganjuk.

Gagal ginjal kronik memiliki prevalensi global yang tinggi dengan prevalensi GGK global yang konsisten antara (11\%) sampai (13\%) dengan mayoritas stadium tiga (Hill dkk., 2016). Pada Desember 2014, terdapat 678.383 kasus $E S R D$, berdasarkan prevalensi yang tidak disesuaikan (proporsi kasar) terdapat 2.067 orang per sejuta penduduk Amerika Serikat (United State Renal Data System [USRDS], 2016). Dari 3,2 juta pasien, sekitar 2,5 juta orang menjalani perawatan dialisis (baik hemodialisis atau dialisis peritoneal), dan sekitar 678.000 orang hidup dengan transplantasi ginjal
(Fresenius Medical Care [FMC], 2014). Di Indonesia prevalensi gagal ginjal kronik berdasarkan yang pernah didiagnosis dokter sebesar $(0,2 \%)$ dari penduduk Indonesia. Jika saat ini penduduk Indonesia sebesar 252.124.458 jiwa maka terdapat 504.248 jiwa yang menderita gagal ginjal kronik. Hanya $(60 \%)$ dari pasien gagal ginjal kronik tersebut yang menjalani terapi dialisis (Kementerian Kesehatan RI [KemenKes RI], 2013). Data untuk wilayah Jawa Timur berdasarkan hasil Riset Kesehatan Dasar tahun 2013 dilaporkan tiga dari sepuluh penduduk berusia $\geq 15$ tahun menderita GGK (Kemenkes RI, 2013). Data dari Pusat Data \& Informasi Perhimpunan Rumah Sakit Seluruh Indonesia (PDPERSI 2013) jumlah klien GGK sekitar 50 orang per satu juta penduduk. Data yang ada di ruang Hemodialisa RSUD Nganjuk pada bulan Oktober 2017 terdapat 62 pasien hemodialisa reguler yang menderita GGK dengan hemodialisa.

Terapi reminiscence merupakan sebuah terapi yang sesuai untuk peran sebagai perawat dimana dalam melaksanakan asuhan keperawatan, perawat mempunyai peran dan fungsi diantaranya pemberi perawatan, sebagai advokat keluarga, pencegahan penyakit, edukator, konselor, kolaborasi, pengambil keputusan etik dan peneliti (Hidayat, 2012). 
Dalam hal ini berarti terapi reminiscence dapat dilakukan oleh perawat yang sesuai dengan salah satu peran dan fungsi perawat sebagai konselor. Tujuan dari penelitian adalah untuk mengetahui dan menganalisis pengaruh terapi reminiscence terhadap penurunan tingkat kecemasan pada pasien hemodialisa di Ruang Hemodialisa RSUD Nganjuk.

\section{METODE PENELITIAN}

Desain penelitian ini adalah jenis penelitian kualitatif eksperimen dengan menggunakan desain Pra eksperimental dengan pendekatan one group pre-post test design. Populasi setelah di inklusi sebanyak 16 pasien gagal ginjal kronik dengan hemodialisa. Sampel penelitian sebanyak 15 responden yang didapatkan dengan teknik purposive sampling. Sampel diambil dengan kriteria inklusi pasien yang menjalani hemodialisa teratur 1 minggu 2 kali, bersedia ikut penelitian, memiliki rrentang usia 20-50 tahun dan Mempunyai barang-barang masa lalu pada masa anak-anak, remaja, dewasa (foto atau video / kaset atau baju). Sampel tidak diambil dengan kriteria eksklusi pasien memiliki kondisi lemah (tidak mampu berkomunikasi).

Dalam penelitian ini variabel independen adalah Terapi Reminiscence, variabel dependen adalah Tingkat Kecemasan yang diukur dengan pemberian kuesioner HADS. Kuesioner ini untuk mengukur tingkat kecemasan pada pasien sebelum dan sesudah diberikan terapi.

Penilaian kecemasan terdiri dari 7 indikator pertanyaan. Jika total skor jawaban dengan jumlah nilai $0-7$ dikategorikan cemas ringan, jumlah nilai 8 - 10 dikategorikan cemas sedang, jumlah nilai $11-21$ dikategorikan cemas berat.

Data yang telah dikategorikan kemudian dianalisa dengan uji statistik terhadap data kecemasan menggunakan uji Wilcoxon Sign Rank Test dengan $\alpha=0,05$. Ha ditolak jika $p$ value $>\alpha$ yang berarti bahwa tidak ada Pengaruh Terapi Reminiscence Terhadap Penurunan Tingkat Kecemasan Pasien Hemodialisa Di Ruang Hemodialisa RSUD Nganjuk. Ha diterima jika $p$ value $\leq \alpha$ yang berarti ada Pengaruh Terapi Reminiscence Terhadap Penurunan Tingkat Kecemasan Pasien Hemodialisa Di Ruang Hemodialisa RSUD Nganjuk.

\section{HASIL PENELITIAN}

Tabel 1. Tabulasi Silang Pengaruh Terapi Reminiscence Pada Pasien Hemodialisa di Ruang Hemodialisa RSUD Nganjuk sebelum dan setelah diberikan terapi reminiscence 18 Februari sampai 20 Maret 2018.

\begin{tabular}{llll}
\hline No & Kategori & Pre Tes & Post Tes
\end{tabular}




\begin{tabular}{llcccc}
\hline & \multicolumn{2}{c}{$f$} & $\%$ & $f$ & $\%$ \\
\hline 1 & Cemas Ringan & 6 & 40 & 14 & 93 \\
\hline 2 & Cemas Sedang & 8 & 53,3 & 1 & 7 \\
\hline 3 & Cemas Berat & 1 & 6,7 & 0 & 0 \\
\hline & Jumlah & 15 & 100 & 15 & 100
\end{tabular}

Uji Wilcoxon Sign Rank Test $\rho$ value $=0,007, \rho$ value $\leq \alpha(\alpha=0,05)$

Pada tabel 4.3 menunjukkan bahwa 15 responden sebagian besar yaitu sebanyak 8 responden $(53,3 \%)$ mengalami tingkat kecemasan sedang sebelum diberikan terapi reminiscence, dan 15 responden hampir seluruhnya yaitu sebanyak 14 responden (93\%) mengalami tingkat kecemasan ringan setelah diberikan terapi reminiscence.

Hasil uji wilcoxon sign rank test didapatkan nilai $p$ value $=0,007, p$ value $\leq$ $\alpha(\alpha=0,05)$, sehingga Ha diterima, disimpulkan ada pengaruh terapi reminiscence terhadap tingkat kecemasan pada pasien hemodialisa di Ruang Hemodialisa RSUD.

\section{PEMBAHASAN}

Hampir setengah responden berusia $31-40$ tahun sebanyak 7 responden $(46,5 \%)$. Hampir setengah responden berusia 31-40 tahun yang mengalami tingkat kecemasan sedang sebelum diberikan terapi reminiscence sebanyak 4 responden $(26,6 \%)$.

Sebagian besar responden dengan tingkat pendidikan SMP sebanyak 8 responden (53\%). Hampir setengah responden dengan tingkat pendidikan SMP yang mengalami tingkat kecemasan sedang sebelum diberikan terapi reminiscence sebanyak 6 responden $(40 \%)$.

Hampir seluruh responden berjenis kelamin perempuan sebanyak 12 responden (80\%). Hampir setengah responden berjenis kelamin perempuan yang mengalami tingkat kecemasan sedang sebelum diberikan terapi reminiscence sebanyak 5 responden $(33,3 \%)$.

Kompleksitas masalah yang timbul selama proses hemodialisa akan berdampak pada terjadinya kecemasan pada pasien. Gangguan psikiatrik yang sering ditemukan pada pasien dengan hemodialisa adalah kecemasan (Heldawati, 2014). Isaac (2005) dalam Untari (2014) mengatakan bahwa faktor yang mempengaruhi respon terhadap kecemasan antara individu dan individu yang lain berbeda-beda, salah satunya kecemasan dipengaruhi oleh faktor usia, menurut Isaac (2005) dalam Untari (2014) seseorang yang mempunyai usia lebih muda ternyata lebih mudah mengalami gangguan akibat kecemasan daripada seseorang yang lebih tua. Karena seseorang yang memiliki usia lebih muda lebih mudah 
mengalami gangguan akibat kecemasan daripada seseorang yang lebih tua. Penelitian ini sejalan dengan penelitian yang dilakukan Hari (2015) tentang gambaran kecemasan dan kualitas hidup pada pasien gagal ginjal kronik yang menjalani hemodialisa terhadap 30 responden bahwa ada hubungan antara usia dengan kecemasan.

Usia dapat mempengaruhi tingkat kecemasan yang dialami pasien hemodialisa. Pasien hemodialisa yang masih muda cenderung memiliki tingkat kecemasan yang lebih tinggi dikarenakan adanya kemungkinan masih banyak harapan-harapan hidup yang belum dapat tercapai sehingga akan mempengaruhi psikologi pasien yang akhirnya memicu terjadinya gangguan akibat kecemasan.

Pasien yang memiliki pendidikan lebih tinggi akan mempunyai pengetahuan yang lebih luas sehingga memungkinkan penguasaan diri dalam menghadapi masalah, mudah mengerti tentang apa yang dianjurkan oleh petugas kesehatan yang dapat mempengaruhi sikap dan perilaku yang positif sehingga pasien bisa menerima kondisi yang dirasakannya serta dapat mengurangi kecemasan sehingga dapat membantu individu tersebut dalam membuat keputusan (Notoatmodjo, 2010). Hal ini sejalan dengan penelitian Jangkup (2015) tentang tingkat kecemasan pada pasien gagal ginjal kronik (GGK) yang menjalani hemodialisa di BLU RSUP Prof. DR. D. Kandau Manado terhadap 40 orang responden bahwa ada hubungan tingkat pendidikan dengan tingkat kecemasan pasien gagal ginjal kronik yang menjalani hemodialisa. Peneliti menyebutkan bahwa tingkat pendidikan seseorang akan berpengaruh terhadap kemampuan berpikir, semakin tinggi tingkat pendidikan akan semakin mudah berpikir secara rasional dan menangkap informasi baru termasuk dalam menganalisa hal baru. Tingkat pendidikan yang rendah dapat mempengaruhi kecemasan yang tinggi pada pasien gagal ginjal kronik yang menjalani hemodialisa.

Tingkat pendidikan yang rendah akan mempengaruhi sikap, pola berpikir seseorang dalam pengambilan keputusan dan juga mempengaruhi penyerapan informasi baru yang didapat. Sehingga ketika pasien hemodialisa dihadapkan dengan kenyataan adanya perbedaan kondisi kesehatan yang tidak lagi sama dengan kondisi yang sebelumnya, akan sulit untuk menerima kenyataan dan terkurung dalam kesedihan yang panjang serta cenderung memiliki tingkat kecemasan yang tinggi. Sebaliknya tingkat pendidikan yang lebih tinggi akan dengan mudah menerima kenyataan dan tidak berlarut-larut dalam kesedihan yang panjang dikarenakan mempunyai 
pemikiran yang lebih luas, pemahaman yang baik akan informasi baru yang di dapat dan dapat lebih bijak menyikapi dan mengatasi permasalahan hidup yang ada.

Hari (2015) menyatakan bahwa jenis kelamin perempuan lebih sering mengalami kecemasan daripada laki-laki hal ini disebabkan karena laki-laki dengan mudah dapat mengatasi sebuah stresor oleh karena itu laki-laki dapat lebih rileks dalam menghadapi sebuah masalah. Penelitian ini sejalan dengan penelitian Purwati \& Wahyuni (2016) yang menyatakan perempuan cenderung mudah cemas dengan berbagai penyebab seperti ketidakstabilan hormon esterogen dan progresteron. Selain itu juga, penampilan merupakan hal yang sangat penting bagi perempuan pada umumnya. Namun, pada penderita gagal ginjal kronik terjadi perubahan fisik yang mengubah citra diri seseorang menjadi kurang menarik seperti warna kulit menjadi coklat keabu-abuan, kering dan gatal, rambut tipis mudah rontok dan patah serta berat badan bertambah akibat edema.

Tingkat kecemasan yang dimiliki laki-laki dan perempuan sangatlah berbeda. Cara menyikapi permasalahan pun juga berbeda. Laki-laki cenderung memiliki sifat santai, kontrol emosi yang relatif stabil dan sikap yang rileks serta tidak terlalu larut akan masalah yang menimpanya.
Sebaliknya perempuan akan lebih sensitif, berlarut-larut dalam masalah yang menimpanya dan sulit untuk dapat mengatasi permasalahan yang sedang dihadapi, sehingga tingkat kecemasan perempuan akan lebih tinggi dibanding tingkat kecemasan yang dialami oleh lakilaki.

Tingkat kecemasan di pengaruhi oleh berapa lama pasien menjalani tindakan hemodialisa. Pada pasien yang baru menjalani tindakan hemodialisa rata-rata yang didapatkan adalah tingkat kecemasan berat karena pada periode awal pasien merasa berputus asa dan tidak dapat sembuh seperti sedia kala. Setelah terapi berkelanjutan ( $>6$ bulan), pasien mulai dapat beradaptasi dengan baik serta tingkat kecemasan mulai menurun (Wartilisna, 2015). Penelitian yang mendukung ialah penelitian yang dilakukan oleh Rahman (2013) terhadap 22 responden bahwa ada hubungan antara lama menjalani tindakan hemodialisa dengan tingkat kecemasan pasien di ruangan hemodialisa RSUD Labuang Baji Pemprov Sulawesi Selatan.

$$
\text { Rentang waktu lama ( }>6 \text { bulan) }
$$
menjalani hemodialisa dapat lebih mempengaruhi tingkat kecemasan pasien. Semakin lama menjalani proses hemodialisa maka dengan sendirinya pasien akan terbiasa menggunakan semua alat dan proses yang dilakukan saat 
melakukan hemodialisa, sementara pasien yang pertama menjalani proses hemodialisa merasa bahwa ini merupakan suatu masalah yang sedang mengancam dirinya dan merasa bahwa hal yang dilakukan ini sangat menyiksanya. Sehingga pada pasien yang baru menjalani tindakan hemodialisa ratarata yang didapatkan adalah tingkat kecemasan berat. Setelah terapi yang dijalani sudah cukup lama, pasien mulai dapat beradaptasi dengan baik sehingga akan terjadi perubahan tingkat kecemasan pada pasien.

Hampir setengah responden berusia 31-40 tahun sebanyak 7 responden (46,5\%). Hampir setengah responden berusia 31-40 tahun yang mengalami tingkat kecemasan ringan setelah diberikan terapi reminiscence sebanyak 7 responden $(46,5 \%)$.

Hampir seluruh responden berstatus menikah sebanyak 14 responden (46,5\%). Hampir seluruh responden berstatus menikah yang mengalami tingkat kecemasan ringan setelah diberikan terapi reminiscence sebanyak 13 responden $(86,6 \%)$.

Penderita Gagal Ginjal Kronis usia muda akan mempunyai motivasi hidup yang lebih baik oleh karena biasanya kondisi fisiknya yang lebih baik dibanding yang berusia tua. Penderita yang dalam usia produktif merasa terpacu untuk sembuh mengingat dia masih muda mempunyai harapan hidup yang tinggi. Usia juga erat kaitannya dengan prognose penyakit dan harapan hidup mereka yang berusia diatas 55 tahun. Kecenderungan untuk terjadi berbagai komplikasi yang memperberat fungsi ginjal sangat besar bila dibandingkan dengan yang berusia dibawah 40 tahun (Desita, 2010). Sejalan dengan Penelitian yang dilakukan oleh Suratih; Suranah; Riyanto (2014) yang dilakukan di bagian Renal Unit Rumah Sakit Umum Daerah di wilayah Kabupaten Semarang terhadap 30 responden bahwa ada hubungan antara usia dengan kualitas hidup.

Pasien GGK yang menjalani hemodialisa dengan usia kurang dari 40 tahun dan tidak lebih dari 55 tahun memiliki motivasi dan harapan hidup yang lebih tinggi bila dibandingkan dengan pasien GGK yang berusia lebih dari 55 tahun. Usia yang lebih muda akan lebih semangat dalam mengikuti proses hemodialisa dikarenakan masih ada banyak harapan yang mungkin belum dapat tercapai sehingga akan menjadi motivasi tersendiri untuk selalu rutin melakukan terapi hemodialisa. Sedangkan pasien yang dalam usia yang tidak lagi produktif kurang mempunyai semangat dan motivasi untuk sembuh mengingat mereka sudah tua sehingga tidak mempunyai harapan hidup lagi. 
Scott, et al.,(2010) menyatakan bahwa perkawinan dapat mengurangi risiko terjadinya kecemasan pada pasien. Perkawinan menghubungkan seseorang dengan individu lainnya, lalu dengan kelompok sosial, dan kemudian institusi sosial yang membuat individu tersebut memiliki tambahan dukungan sosial (Stolzenberg, Loy, \& Waite, 1995) dalam Wade, Hart, Wade, Bajaj, dan Price, 2013). Menurut Ratna (2010) dukungan dari keluarga terutama pasangan merupakan faktor penting seseorang ketika menghadapi masalah (kesehatan) dan sebagai strategi preventif untuk mengurangi stress dan pandangan hidup yang negatif. Dukungan keluarga sangat diperlukan dalam perawatan pasien, dapat membantu menurunkan kecemasan pasien, meningkatkan semangat hidup dan komitmen pasien untuk tetap menjalani pengobatan. Didukung oleh penelitian yang dilakukan oleh Zurmeli; Bayhakki; Utami (2015) terhadap 105 responden bahwa ada hubungan antara dukungan keluarga dengan kecemasan.

Besar atau tidaknya dukungan yang diterima dari pasangan oleh penderita gagal ginjal kronik sangat menentukan perjalanan penyakit dan ketersediaan menjalani terapi. Dukungan dapat berupa motivasi, penghargaan, perhatian dan pemberian solusi. Dengan dukungan dari pasangan hidup, penderita gagal ginjal kronik dapat mengalami perubahan emosional seperti merasa diperhatikan serta lebih semangat untuk menjalani hidup. Perubahan emosional tersebut bisa merubah perjalanan penyakit ke arah yang lebih baik sehingga tingkat kecemasan dapat menurun. Dengan adanya semangat, motivasi dan harapan yang tinggi tersebut, dapat membantu keberhasilan penanganan kecemasan dengan terapi reminiscence yang digunakan dalam pelitian ini.

Pengaruh terapi reminiscence terhadap penurunan tingkat kecemasan sangat kuat kaitannya. Ketika proses terapi reminiscence berlangsung, akan ada suatu impuls pada memori. Memori adalah proses penyimpanan impuls sensorik penting untuk dipakai pada masa yang akan datang sebagai pengatur aktivitas motorik dan pengolahan berpikir. Sebagian besar penyimpanan ini terjadi dalam korteks serebri. Korteks yang mempunyai sel otak lebih dari 10 milyar sel berhubungan dengan sel-sel lain didaerah otak. Tiap sel otak mempunyai hubungan dengan 400010.000 sel otak lainnya dan berhubungan melalui impuls litrik dan zat kimia yang disebut zat penghantar rangsang atau neurotransmitter. Proses penyimpanan informasi juga merupakan fungsi dari sinaps. Oleh karena itu, pada setiap macam sinyal sensorik tertentu yang melewati 
serentetan sinaps dimasa datang akan lebih mampu menjalarkan sinyal yang sama, proses penyampaian sinyal ini disebut fasilitasi. Bila sinaps itu sudah seringkali dilewati oleh sinyal sensorik maka sinyal itu akan begitu terfasilitasi sehingga sinyal yang timbul dari otak sendiri saja sudah dapat menjalarkan impuls melalui serentetan sinaps yang sama walaupun belum timbul masukan sensoris (Lahey, 2012; Santrock, 2012).

Pemikiran bawah sadar (sub conscious mind) bermula dari kegiatan fasilitasi sinaps ini. Hal ini akan menimbulkan suatu persepsi dari pengalaman sensasi yang sebenarnya dan dapat mempengaruhi respon tubuh. Walaupun pengaruh atau akibat yang timbul hanyalah suatu memori dari suatu sensasi, sekali memori itu disimpan di sistem saraf, maka memori itu akan menjadi bagian dari mekanisme pengolahannya. Proses masuknya informasi ke sistem ingatan manusia melalui saraf pendengaran dan penglihatan. Ingatan sensori ini sangat mudah hilang karena kapasitasnya yang sedikit. Indera-indera yang bekerja untuk menangkap informasi yang banyak akan mengakibatkan terjadinya kelupaan. Informasi yang dianggap relevan dan penting bagi individu akan diteruskan dan masuk ke ingatan jangka pendek. Ingatan jangka pendek juga memiliki kapasitasnya sendiri, yaitu sekitar 30 detik dan apabila informasi yang dianggap relevan dan penting bagi individu ini tidak diulang maka informasi tersebut dapat hilang, atau informasi tersebut dilupakan. Hippocampus merupakan bagian otak yang menyimpan memori. Peran hippocampus adalah membantu pemindahan informasi dari ingatan jangka pendek menjadi ingatan jangka panjang. Informasi yang berhasil masuk ke ingatan jangka pendek akan diteruskan ke ingatan jangka panjang, ingatan jangka panjang merupakan tempat penyimpanan informasi yang relatif permanen (Lahey, 2012; Santrock, 2012).

\section{KESIMPULAN}

Terapi Reminiscence di Ruang Hemodialisa RSUD Nganjuk yaitu sebanyak 15 responden, 8 responden $(53,3 \%)$ mengalami tingkat kecemasan sedang sebelum diberikan terapi reminiscence, dan 14 responden (93\%) mengalami tingkat kecemasan ringan setelah diberikan terapi reminiscence. Ada pengaruh terapi reminiscence terhadap penurunan tingkat kecemasan pada pasien gagal ginjal konik dengan hemodialisa dengan hasil uji wilcoxon sign rank test didapatkan nilai $p$ value $=0,007 \leq \alpha=0,05$, sehingga Ha diterima.

DAFTAR PUSTAKA 
Desita. 2010. Pengaruh Dukungan Keluarga Terhadap Peningkatan Kualitas HidupPasien Gagal Ginjal Kronik yang Menjalani Hemodialisa di RSUP HAM Medan. Universitas Sumatera Utara. http://repository.usu.ac.idbitstream 123 456789391554Chapter\%2010.pdf (diakses tanggal 25 April 2018 jam 20.59).

Fresenius Medical Care. (2014). ESRD patients in 2010: $\mathrm{A}$ global perpective.http://www.visionfmc.com/f iles/pdf/ERSDPatientsin2010.pdf (diakses tanggal 15 Oktober 2017 jam 20.10).

Hari (2015). Gambaran Kecemasan dan Kualitas Hidup Pasien Gagal Ginjal. ejournal

Keperawatan.https://media.neliti.com/ media/publications/186945-ID-

hubungan dukungan-keluarga-dengankualit.pdf (diakses tanggal 25 April 2018 jam 21.05).

Heldawati,. Sudirman,. Rahman, A. (2014). Hubungan Tindakan Hemodialisa dengan Tingkat Kecemsan Pasien di Ruangan Hemodialisa RSUD Labuang Baji Pemprov Sulawesi Selatan. Issn : 23021721.https://www.scribd.com/document/ 331476760/KECEMASAN-PASIENGAGAL-GINJAL-KRONIK-YANGMENJALANI-HEMODIALISA (diakses tanggal 25 April 2018 jam 20.10).

Hill, N.R., Fatoba, S. T., Oke, J.L., Hirst, J.A., O'Challaghan, C.A., Lasserson, D.S., Hobbs, F.D.R. (2016). Global prevalence of chronic kidney diseasea systematic review and meta-analysis. Reseach Article: Plos One. DOI:10.1371/journal.pone.0158765. https://www.ncbi.nlm.nih.gov/pmc/art icles/PMC4934905/ (diakses tanggal 27 September 2017 jam 18.03).

Jangkup, J.K,. Elim, C, Kandou, L.J. (2015). Tingkat Kecemasan Pada Paien Penyakit Jantung Koroner (PJK) Yang Menjalani Hemodialisa
Di BLU RSUP Prof. Dr. R. D. Kandou Manado. Jurnal e-Clinic Vol 3 Nomor 1.

https://www.scribd.com/document/33 1476760/KECEMASAN-PASIENGAGAL-GINJAL-KRONIK-YANGMENJALANI-HEMODIALISA (diakses tanggal 25 April 2018 jam 20.33).

Jevuska. (2012). Gagal ginjal kronik atau CKD : Pengertian dan klasifikasi. https://www.jevuska.com/2012/10/27/ gagal-ginjal-kronik-atau-ckd/ (diakses tanggal 25 April 2018 jam 20.59)

Kementerian Kesehatan RI. (2013) Survei Demografi Kesehatan Indonesia Laporan Pendahuluan.

Lahey, B.B. (2012). Psychology : An introduction, 9th Ed. New York : The Mc. Graw-Hill Companies. http://www.erlangga.co.id/psikologipe rti/7806-life-span-development-edisi13-jilid-1-a-2.html (diakses tanggal 20 November 2017 jam 21.22).

Masoudrayyani, M., L., Forouzi, M.A., \& Razban, F. (2014). Self-care selfefficacy and quality of life among patients receiving hemodialysis in SouthEast of Iran. Asian J.Nursing Edu. and Research 4(2): April-June 2014, ISSN-2231-1149.

Notoatmodjo. 2010. Metodologi Penelitian Ilmu Keperawatan, Pedoman Skripsi, Tesis, Dan Instrumen Penelitian Keperawatan. Jakarta: Salemba Medika.

[PDPERSI ] Pusat Data dan Informasi. 2013. www.pdpersi.co.id (diakses tanggal 17 Oktober 2017 jam 19.45).

Rahman, A 2013. Hubungan Tindakan Hemodialisais Dengan Tingkat Kecemasan Pasien Di Ruangan Hemodialisa Rsud. Labuang Baji Pemprov Sulawesi Selatan" PDF di publikasikan. ejournal Keperawatan (e-Kp) Volume 3. Nomor 1. Februari 2015 (diakses tanggal 25 April 2018 jam 20.49).

Ratna (2010). Gambaran Kecemasan dan Kualitas Hidup Pasien Gagal Ginjal. 
ejournal

Keperawatan.

https://media.neliti.com/media/publica tions/186945-ID-hubungan-dukungankeluarga-dengan-kualit.pdf (diakses tanggal 25 April 2018 jam 21.05).

Santrock, J.W. 2012. Life-Span Development: Perkembangan Masa Hidup. (Penerj. Achmad Chusairi, Juda Damanik; Ed. Herman Sinaga, Yati Sumiharti). Jakarta: Erlangga.

Scott, K. M., Wells, E., Angermeye, M., Brugha, T., Bromet, E., Demyttenaere, K., Girolamo, K...Kessler, R.(2010). Gender and the relationship between marital status and first onset of mood, anxiety, and substance use disorders. Psychol Med, 9, 1495-505.doi: $10.1017 / \mathrm{S} 0033291709991942$

https://media.neliti.com/media/publica tions/111901-ID-stres-dan-tingkatkecemasan-saat-ditetap.pdf (diakses tanggal 25 April 2018 jam 20.14).

Slametiningsih (2012). Pengaruh Logo terapi Individu Paradoxical Intention Terhadap Penurunan Kecemasan Pada Pasien Gagal Ginjal Kronik (Ggk) Yang Menjalani Terapi Hemodialisa Di Rs Islam Cempaka Putih Jakarta Pusat. Tesis: Fakultas Ilmu Keperawatan Program Studi Magister Keperawatan Peminatan Keperawatan Jiwa, UI. http://www.digital_20306156-

T30971-Pengaruh ${ }^{-}$logoterapi.pdf (diakses tanggal 25 Oktober 2017 jam 17.25).

United States Renal Data System. USRDS (2016) : Incidence, prevalence, patient characteristics and treatment modalities in ESRD.USRDS [internet]. http://www.usrds.org (diakses tanggal 27 September 2017 jam 19.18).

Untari. I. (2014). Faktor-faktor Yang Mempengaruhi Kecemasan Pada Usia Pertengahan Dalam Menghadapi Proses Menua (Aging Process). Jurnal Keperawatan Akper 17 Karanganyer Vol 1 No 2. Issn: 2338-6800 https://www.scribd.com/document/33 1476760/KECEMASAN-PASIEN-
GAGAL-GINJAL-KRONIK-YANGMENJALANI-HEMODIALISA (diakses tanggal 25 April 2018 jam 20.55).

Wartilisna (2015). Hubungan Tindakan Hemodialisa Dengan Tingkat

Kecemasan Klien Gagal Ginjal Di Ruang Dahlia RSUP Prof Dr.R.D.Kandou Manado. ejournal Keperawatan (e-Kp) Volume 3. Nomor 1. Februari 2015. http://digilib.stikeskusumahusada.ac.i d/files/disk1/31/01-gdl-yaniekohar1508-1-yanieko-).pdf (diakses tanggal 28 Mei 2018 jam 07.44).

Zurmeli; Bayhakki; Utami (2015). Gambaran Kecemasan dan Kualitas Hidup Pasien Gagal Ginjal. ejournal Keperawatan.

https://media.neliti.com/media/publica tions/186945-ID-hubungan dukungankeluarga-dengan-kualit.pdf (diakses tanggal 25 April 2018 jam 21.05). 